\title{
INTEGRATED WATER RESOURCES MANAGEMENT AS A TOOL FOR DROUGHT PLANNING AND MANAGEMENT IN BOTSWANA: A DIAGNOSTIC APPROACH
}

\author{
P.K. KENABATHO ${ }^{1} \&$ M. MONTSHIWA ${ }^{2}$ \\ ${ }^{1}$ Department of Environmental Science, University of Botswana, Botswana. \\ ${ }^{2}$ Every River Has Its People Project, Kalahari Conservation Society, Botswana.
}

\begin{abstract}
Water is an essential resource affecting many aspects of development as well as the natural environment. Development, planning and management strategies of this resource should therefore be effective if drought and other extreme disasters are to be minimized. Sustainable water resource management must also balance between the short-term needs of the people for their social and economic development and the long-term protection of the natural resource base. Therefore, there should exist an enabling environment in the form of policies and legislative frameworks which are flexible and more integral, institutional frameworks that allow for infusion of stakeholders into water resources planning and management strategies through capacity building and empowerment, and sound management instruments geared towards efficient use of water through a water-oriented society and information sharing support systems. These are captured under the concept of Integrated Water Resources Management (IWRM) - a process that promotes the coordinated development and management of water, land and related resources in order to maximize the resultant economic and social welfare in an equitable manner without compromising the sustainability of vital ecosystems. This is a challenge to any nation that desires to meet the aspirations of the United Nations' water-related Millennium Development Goals by way of providing equitable access to water of acceptable quality and quantity. In investigating strategies for effectively planning for and managing the effects of drought, which are eminent in Botswana, a diagnostic approach using IWRM was adopted. Also, a few lessons and experiences drawn from some countries within and outside the Southern African region were provided as possible models that can help contain the effects of drought in Botswana. The paper concludes that with the current fragmented, uncoordinated institutional and legal arrangements in water resources management, there is an urgent need to go the route of integrated water demand management as envisaged in the overall concept of IWRM.
\end{abstract}

Keywords: enabling environment, institutional roles, integrated water resources management, management instruments, water demand management.

\section{INTRODUCTION}

According to the Global Water Partnership (GWP) [1], Integrated Water Resources Management, commonly abbreviated as IWRM, is a coordinated development and management of water, land and related resources in order to maximize the resultant economic and social welfare in an equitable manner without compromising the sustainability of vital ecosystems. This includes more coordinated development and management of land and water, surface and groundwater, potable and wastewater as well as upstream and downstream interests in river courses. IWRM is not just about managing physical resources; it is also about reforming human systems to enable people to benefit from those resources. Simply put, IWRM is a tool for change, a long-term and forward moving process that is iterative in nature as shown in Fig. 1 [2]. It has no beginnings or ending, but it is responsive to change and adaptive to new economic, social and environmental conditions, and therefore does not mean throwing everything and starting over again. Since Botswana has been experiencing water-related drought for the last 4 years, and the situation is worsening every year particularly in the southern and western parts of Botswana, the time is ripe for the management of this scarce resource in an integrated and coordinated manner through an IWRM approach. The situation is so bad that some of the major dams, which serve the greater population of Botswana, especially in cities and towns, have reached their lowest storage levels ever in their history. Gaborone dam, which is located within the 


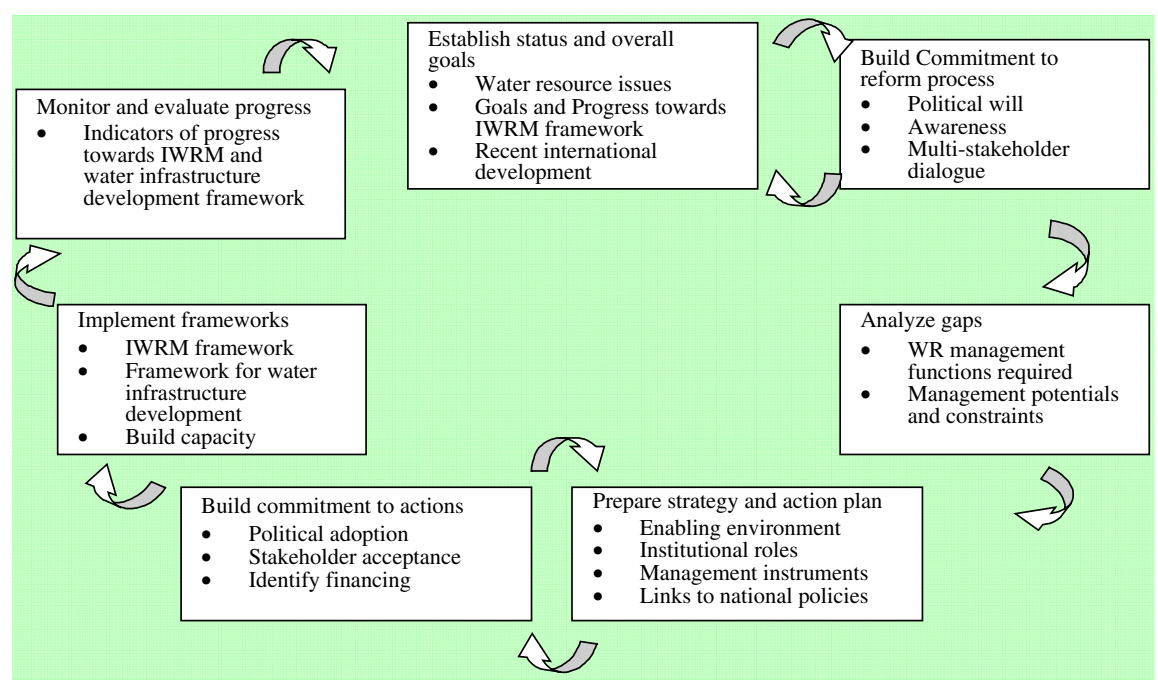

Figure 1: IWRM as an ongoing process to respond to changing situations and needs.

capital city of Gaborone and is the largest dam with a capacity of 141 million cubic metres (MCM) stands at 20\% capacity, has not received any significant inflows since it last spilled in December 2001. Shashe ( 87 MCM) and Letsibogo (100 MCM) dams situated in northeastern Botswana stand at 77 and $75 \%$ capacity, respectively [3]. The latter is used to augment the resources of Gaborone dam through a $360 \mathrm{~km}$ transfer pipeline known as the North-South Water Transfer Scheme, and plans are at an advanced stage to connect the former to this transfer scheme. Although the northern dams are not so bad compared to the southern dams, the situation is likely to worsen due to the overwhelming demand at the receiving end (southern Botswana). Furthermore, these dams are located in semi-arid flat terrains that have a large surface area-volume ratio, which contributes to enormous loss of water through evaporation [4] in addition to the escalating demand. In view of these reasons, it is very important that the management of water resources in Botswana should take an integrated dimension if sustainability is to be achieved.

\section{DESCRIPTION OF THE STUDY AREA}

\subsection{Botswana's geographic and climatic settings}

Botswana is located in the centre of the Southern African region spread over an area of $582,000 \mathrm{~km}^{2}$ bounded between $18^{\circ} \mathrm{S}$ and $27^{\circ} \mathrm{S}$ latitudes and longitudes $20^{\circ} \mathrm{E}$ and $29^{\circ} \mathrm{E}$, north of South Africa, between Namibia and Zimbabwe (Fig. 2). It is completely land locked with the shortest distances from the capital city Gaborone to the Indian and Atlantic oceans being about 675 and $1025 \mathrm{~km}$, respectively. The climate of Botswana is very typical of Southern Africa, influenced by the size and shape of the southernmost finger-like tip of the African continent. The location of the country in relation to the general circulation and the relatively flat terrain also has a bearing on the country's climate. For these reasons Botswana is regarded as a semi-arid country, which receives variable and low average rainfall to the tune of $450 \mathrm{~mm}$ spread between the rainy season of November and March, far less than the evaporation which is about $2000 \mathrm{~mm}$ per annum. The northern part of Botswana receives a relatively 


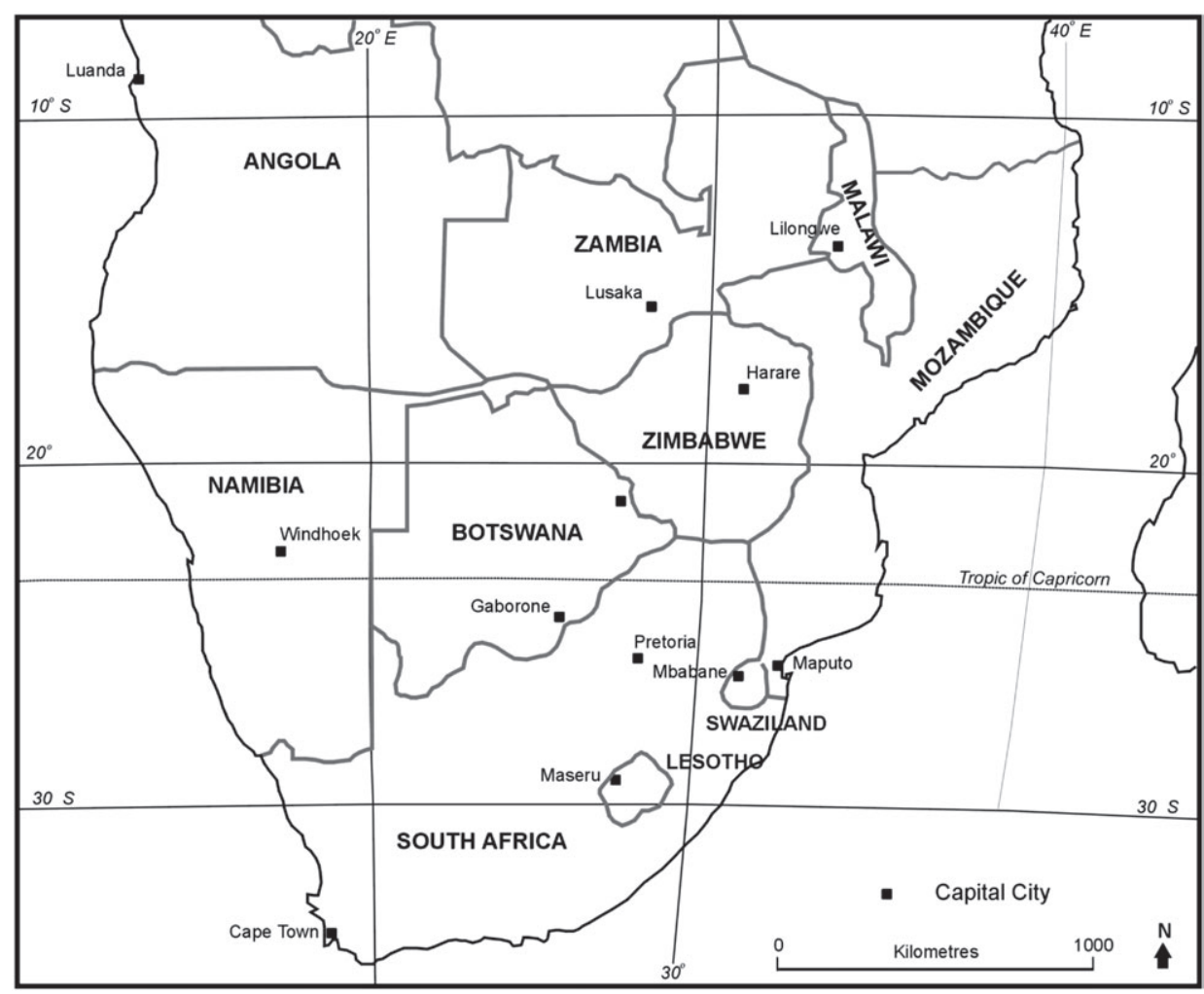

Figure 2: Location map of Botswana.

higher annual rainfall to the order of $600 \mathrm{~mm}$, compared to $350 \mathrm{~mm}$ in the southern parts of Botswana. Due to the semi-aridity of the country, most of the rivers originating in the country are ephemeral with the average flow period being between 10 and 70 days in a year. The rivers originating from outside the country, mainly Okavango that drains into the Okavango Delta and Zambezi in the northern side of the country, are however perennial but contribute less runoff to the entire drainage system of Botswana. For the past 4 years Botswana has been experiencing drought with rainfall skewed towards normal to below normal, with delayed and shortened rainy seasons. This has led to reduction in inflows to the dams as well as recharging of aquifers especially in the southern part of the country, which has affected many aspects of life including agriculture and general water supplies. For these reasons, the President of Botswana has consecutively declared the country as drought stricken for the last 4 years, including 2005 .

\subsection{Economic and demographic factors}

According to Gaolathe [5] Botswana's economy currently enjoys strong positive growth with a GDP of $5.7 \%(2003 / 2004)$, although this is slightly lower than the previous year which stood at $7.8 \%$. While this growth rate is higher than the regional 2004 projections of $4.8 \%$, it is still lower than the growth rate of $7 \%$ required to meet the United Nations' Millennium Development Goals as well as targets for the newly established New Partnership for Africa's Development. Diamond mining has 
fuelled much of the expansion and currently accounts for more than one-third of the GDP and for $70-80 \%$ of the export earnings. Tourism, financial services, subsistence farming and cattle rearing are other key sectors. The rate of unemployment is $23.8 \%$ and the people living below the poverty datum line is $30 \%$ compared to $47 \%$ in $1993 / 1994$ periods. The population is over 1.68 million [6], $52.1 \%$ of whom now live in urban areas compared to $45.7 \%$ in 1991 and a mere $12 \%$ in 1975 [6]. The annual population growth between 1991 and 2001 was $2.33 \%$ compared with $3.5 \%$ between 1981 and 1991. Botswana's capital city, Gaborone, has the highest proportion of the country's population, about $11 \%$, as in 2001. In view of these economic factors, Botswana is considered among the fastest developing countries in Africa albeit with high dependencies on the mining sector. For this reason, the government of Botswana has intensified its efforts for economic diversification in order to maintain a stable economy. But all these efforts have a bearing on the already limited water resources.

\subsection{Water availability and demand}

In areas with a semi-arid climate, high evaporation and low rates of recharge, increasing demand, and other related factors, protection and conservation of water resources become important. Surface water resources in particular are very limited, with the highest concentration being in the northeastern and northwestern regions that receive relatively good rains and have a networks of rivers, some of which are perennial and originate from other countries (e.g. the Okavango and Chobe rivers). The total volume of surface runoff is low, about $2100 \mathrm{MCM}$ per year, but extremely variable in occurrence and distribution, ranging between 1.2 and $50 \mathrm{~mm}$ per year. In addition to these, there are recurrent droughts particularly in the southern part of Botswana as mentioned earlier, as well as increased water demand due to significantly high population. These factors combined make the area more prone to water shortages, which ultimately affects the performance of the dams in these regions. Currently, the Gaborone dam has been overtaken by a huge water demand as it also serves the surrounding villages and towns. The dam was designed to yield $10 \mathrm{MCM}$ per annum compared to the current annual demand of about $33 \mathrm{MCM}$. In addition to this are the losses through evaporation, which are in excess of $20 \%$ annually [4, 7, 8]. Currently, Gaborone dam is only $20 \%$ full as of July 2005 and has been categorized as severe in relation to the drought model adopted by the Water Utilities Corporation (WUC), and is estimated to last for only 4 months of supply [8]. Similarly, other dams are also at different stages of drought, although the northern dams are relatively better as shown in Table 1 below. The situation has been worsened by the fact that there have not been any significant inflows into the dam since it last spilled in 2001, and WUC has introduced some water restrictions in order to reduce the demand within Gaborone and the surrounding villages by $25 \%$. Regarding water supply for major villages, the Department of Water Affairs (DWA) currently serves about 522,000 people through the 17 Major Village Water Scheme, with a total annual consumption of 18 MCM in 2002/2003 period

Table 1: Percentage dam levels, period of supply and drought situation as of July 2005.

\begin{tabular}{lcccl}
\hline Dam & Capacity (MCM) & \% level & $\begin{array}{c}\text { Months of supply } \\
\text { without inflow }\end{array}$ & Drought status \\
\hline Gaborone & 141.4 & 21 & 4 & Severe \\
Bokaa & 18.5 & 24.7 & 4 & Severe \\
Letsibogo & 100.0 & 75.1 & 24 & Moderate \\
Shashe & 85.3 & 76.9 & 17 & Moderate \\
\hline
\end{tabular}


compared to $17 \mathrm{MCM}$ in 2001/2002, representing an increase of 5\%. In the same 2002/2003 period, the total production of water stood at 23 MCM compared to 21 MCM in 2001/2002, which represents an increase of $9 \%$. The production levels are higher than consumption mainly due to water losses in the water distribution networks, which represents average losses of close to 30\% [9]. Worse still, more than $80 \%$ of this water is mainly groundwater, which is rarely replenished due to less recharge rates.

It is very clear from the above points that both urban and rural areas have serious water shortage which is compounded by huge losses and escalating demand. The management of the limited water resources in these areas therefore needs to be responsive and integrated if sustainability is desired. It is for these reasons that IWRM is adopted as an approach that can improve the management of water resources in Botswana.

\section{THE APPROACH: IWRM PRINCIPLES, STRATEGIES AND AREAS OF CHANGE}

In order to ascertain whether IWRM can be used as a tool for drought planning and management, a diagnostic approach which unveils water management strategies alongside IWRM principles, strategies and areas of change is used to assess and suggest more sustainable management strategies for water resources in Botswana.

\subsection{Principles of IWRM}

The Southern African Development Community (SADC) Water Vision in Global Water PartnershipSouthern Africa (GWP-SA) [10] under the sub-vision of IWRM calls for efficient utilization, equitable access and sharing of the region's water resources to ensure sustainable social, environmental and economic benefits for all. This is also in line with the 2002 World Summit on Sustainable Development (WSSD) call for IWRM/Water Efficiency (WE) plans by all developing countries as a milestone towards attaining the water-related 2015 Millennium Development Goals. The key principles of IWRM are summarized below:

1. efficient use of water through water demand management, conservation and reuse, and the efficient use of water for agriculture;

2. integration of water supply, sanitation, and health and hygiene education programmes;

3. integrated, people-centred planning (gender-specific needs, poverty alleviation, social justice, equitable access to affordable safe water and sanitation for basic human needs);

4. capacity building (knowledge and skills for water, waste and sanitation managers);

5. effective public consultation, education and involvement of users in water resources management;

6. recognition of the environment as a legitimate user of water;

7. protection of the environment through appropriate user charges;

8. safe management of water close to the point of generation;

9. prevention of export/import of harmful waste across national and regional boundaries.

These principles combined make identifying and implementing effective solutions to water management much easier. These also avoid the all too common situation where solving one problem creates another especially when solutions are sought within the box of traditional sectoral, top-down, supply fix, as well as command-and-control approaches. The break from this tradition will promote consideration of environmental impacts from the outset and hence ensure maximum social, economic as well as environmental returns. 


\subsection{Effective water governance}

In line with the above IWRM principles, there is a need for efficiency in water governance and management. Since this paper has adopted a diagnostic approach with regard to water governance in Botswana, an attempt is made to find an entry point towards applying the IWRM approach. It is therefore important to recall and summarize the principles of effective water governance [1], which will serve as a yardstick throughout the text as to how Botswana is scaling in terms of key IWRM principles.

- Openness and transparency: Institutions need to work in an open and transparent manner in the management of water resources.

- Inclusive and communicative approach: Improved participation depending on all levels of governance. This is likely to create more confidence in the end result and in the institutions that deliver policies.

- Water policies and actions must be coherent and integrative.

- Performance and operation: Good governance requires that processes and operations are accountable. The roles and responsibilities in the legislative and executive processes need to be clear. Each institution must explain and take responsibility for what it does.

- Efficiency: Providing economic efficiency, and also concepts of political, social and environmental efficiency, must be upheld.

- Responsive and sustainable: Policies must deliver what is needed on the basis of demand; clear objectives and evaluation of future impact, and where available, of past experience.

To put the above points in perspective, the status quo of water governance in Botswana is summarized below [11]:

1. institutional and policy fragmentation: more than five water authorities working independent of each other without cross-sectoral coordination, as well as fragmented pieces of legislation and policies many of which are outdated;

2. water authorities provide water and monitor themselves on issues of quality and environmental protection;

3. poor maintenance schemes and accountability in major villages resulting in water losses of over $30 \%$ annually, and these villages depend on groundwater which is not replenished;

4. lack of integrated planning leading to closed-sectoral planning of water resources;

5. lack of relevant policies and byelaws to empower water authorities;

6. lack of early warning systems for disasters such as drought and floods;

7. lack of integrated educational programmes on water and environment in curriculum;

8. minimal public-stakeholder consultation, collaboration and involvement in water resources planning and management;

9. consultancies/tender-based development and management approach which has little to no extensive sustained research component owing to weak collaboration with research institutes.

These diagnoses of water governance in Botswana provide a benchmark upon which areas of change can be identified and prioritized in moving along the IWRM path.

\subsection{IWRM strategies and areas of change}

From the preceding background, it is evident that there is a need to adopt a more sustainable and integrated approach to water development and management that requires change in many areas and at 


\begin{tabular}{|c|c|}
\hline & THE ENABLING ENVIRONMENT \\
\hline 1.1 & Policies: setting goals for water use, protection and conservation \\
\hline 1.2 & Legislative framework: the rules to follow to achieve policies and goals \\
\hline \multirow[t]{2}{*}{1.3} & Financing and incentive structures: allocating financial resources to meet water needs \\
\hline & INSTITUTIONAL ROLES \\
\hline 2.1 & Creating an organizational framework: forms and functions \\
\hline \multirow[t]{2}{*}{2.2} & Institutional capacity building: developing human resources and identifying role players \\
\hline & MANAGEMENT INSTRUMENTS \\
\hline 3.1 & Water resources assessment: understanding resources and needs as well as potential benefits \\
\hline 3.2 & Plans for IWRM: combining development options, resource use and human interaction \\
\hline 3.3 & Demand management: using water more efficiently \\
\hline 3.4 & Social change instruments: encouraging a water-oriented civil society \\
\hline 3.5 & Conflict resolution: managing disputes, ensuring sharing of water \\
\hline 3.6 & Regulatory instruments: allocation and water use limits \\
\hline 3.7 & Economic instruments: using value and prices for efficiency and equity in demand management \\
\hline 3.8 & Information management and exchange: improving knowledge for better water management \\
\hline
\end{tabular}

Figure 3: Key areas of change for IWRM.

many levels. A more gradual change which will produce more sustainable results than an attempt to overhaul the whole system in one go is however desirable. Areas and sequence of change, as well as the required time frame given the current social, political and economic situation, need to be identified in order to achieve agreed-upon goals. For these reasons, IWRM areas of change as presented in Fig. 3 [1] are mirrored against situational water governance in Botswana under the three key areas of (i) enabling environment, (ii) institutional roles and (iii) management instruments to identify entry points for which immediate action can be taken in order to deal with the drought situation in the country.

3.3.1 Situational analysis of water governance and indication of IWRM principles in Botswana This section attempts to take stock of the status quo in water governance and implementation of IWRM principles in Botswana. It is worth mentioning that IWRM is not a new concept, instead it is a change of approach in implementing different but associated activities in the management of water resources, i.e. the holistic approach. While the paper does not claim to present a blueprint in addressing the effects of water-related drought, rather it contends that adoption of the IWRM approach can provide another way of avoiding the severe impacts of droughts as well as providing coping mechanisms to a drought-prone country like semi-arid Botswana.

\subsubsection{Enabling environment}

If IWRM is to be used as a tool to ensure the continued availability of water resources for both human use and maintenance of ecological integrity, there is a need to put in place proper and responsive legal framework. The legal framework takes three forms, namely the policy (including regulations and guidelines), national laws and international laws (i.e. conventions and protocols).

In terms of policy, there are currently four acts, namely (i) The Water Act of 1968, (ii) the Borehole Act of 1956, (iii) the Water Works Act of 1962 (as amended in 1983) and (iv) the Water Utilities 
Corporation Act of 1970 (as amended in 1978). In addition to these, the National Water Master Plan of 1991 (currently under review) also guides the development and management of water resources in Botswana. Obviously most of these acts are old and have not been amended to meet the challenges of modern water governance, which are obviously different from the dates of these acts, and require an integrated approach in the management of this scarce resource. Also, these policies operate independent of each other and rarely have mention of the other in their statements. In view of these reasons, it is clear that there is no integrated water policy which is responsive to change in water governance and competent enough to guide sound management of water resources. However, in the absence of this integrated policy, there are several environmentally supportive stand-alone policies that if consolidated could be relevant to the integrated management of water resources. These include the recently launched National Master Plan for Wastewater and Sanitation of 2004, the long awaited Environmental Impact Assessment Policy of 2005, the National Master Plan for Arable Agriculture and Dairy Development of 2002 and the Water Conservation and Water Demand Management Policy (under preparation). But all these timely master plans need legal backing and empowerment for effective policy implementation and monitoring. Also, these plans are limited in scope. They fail to explicitly define the following:

1. policy instrument-which refers to policy tools that can be either command-and-control or market-based policies;

2. policy targets-which refer to intervention areas, e.g. policy can target inputs, outputs or processes;

3. policy addressee - the person or institution to whom the policy is addressed, i.e. whoever has to take account of policy implementation;

4. policy regulation area-different environmental problems have different spatial dimensions, but most of these policies assume a homogeneous space although most resources are unevenly distributed within the country.

Overall, these water-related policies are supposed to be guided and backed by the Water Act of 1968, which has not been reviewed for almost 40 years now. While it is obvious that there is a need for national water laws, regional and international legislations are of great importance in guiding the development and review of national policies because the majority of large watercourses in Southern Africa such as the Limpopo, Zambezi, and Okavango rivers are shared by three or more countries. The regional linkages can be important to Botswana for watercourses in the central part of Botswana which are so far underutilized in as far as water supply is concerned. For example, the Nata-Makgadikgadi system links the Maitengwe riverine system (emerging from Zimbabwe) and the Okavango system (owing its existence to the Kubango and Cuito river basins in Angola). The Limpopo system connects eastern Botswana with South Africa and Zimbabwe. The latter system is earmarked as a potential water source which will cost the government of Botswana close to US\$200 million [5]. Since the current regional SADC Water Policy is at an advanced stage of preparation, and for the fact that there has been thorough consultation with the countries and other partners in the region, Botswana should utilize this opportunity to review all water policies and legislations (including the Water Act) to align them with the regional policy by making them as much integrated as possible. There is a need to allocate sufficient resources for the development and management of water resources. One should acknowledge that it remains a challenge in the whole world in as far as financing of water projects is concerned. In fact, the twinge is felt most by developing countries especially those successfully growing economically where international support is withdrawn, like in the case of Botswana. It is on this breath that the IWRM approach becomes handy since it identifies a stake that everybody can hold including donors and financiers. This is because IWRM provides desirable opportunities for 
funding especially on activities that are seen to be supporting government water efficiency initiatives, hence a need to forge connections and strong relations with regional partnerships such as GWP-SA through its Country Water Partnerships (CWPs). Also, the private sector, which has for a long time been sidelined, need to be taken on board. This can be achieved by developing incentive approaches to encourage investment of the private sector in research and innovation, development and management of water resources.

\subsubsection{Institutional roles and responsibilities}

There are two main areas under the institutional roles and these are institutional organizational frameworks and institutional capacity building. Responsibility for water in Botswana is currently shared between a number of ministries, departments, parastatals and other bodies. The Ministry of Minerals, Energy and Water Resources is responsible for policy formulation, development and management of water resources through the DWA, Department of Geological Surveys and the WUC parastatal. DWA designs, constructs and operates water supply systems in the major villages in order to provide adequate and potable water supplies through the Major Villages Water Supply and Development Scheme. In the smaller villages, the operation of this scheme is the responsibility of the Ministry of Local Government, which is currently charged with the implementation of the Village Water Supply and Sewerage Project. For urban areas, WUC, which operates under a sound commercial basis, has the mandate to provide potable water to all the urban areas and also provide bulk supplies through DWA for onward distribution to the major villages. Other authorities include the Ministry of Agriculture (MoA), which is responsible for the development and management of small dams for agricultural purposes. Since coordination and collaboration are strong components of IWRM, it is imperative that the roles and responsibilities of each authority are clearly defined, and the terms of effective collaboration are established. It is however regrettable that for a long time there has been lack of cross-sectoral linkages and collaboration in the development and management of water resources. In IWRM, collaboration is defined in terms of both horizontal and vertical linkages. Horizontal refers to linkages between and among sectors while vertical refers to societal levels, i.e. user, technical and policy making groups. But effective collaboration is still missing in water governance in Botswana as, in practice, there are still conflicting approaches between sectors. A typical example includes the management of one of the well fields in southeastern Botswana, about $15 \mathrm{~km}$ south of the capital city Gaborone, and Gaborone dam. The Ramotswa well fields, located down slope of the Ramotswa Village, have been abandoned due to pollution from pit latrines. Now because of the drought situation facing the nation, especially in the southern part of Botswana, the DWA together with other relevant institutions are busy assessing the potential for developing the resource for consumption through a recently purchased state-of-the-art water treatment equipment while the MoA on the other hand is assessing the same resource, and has just hired an environmental impact assessment consulting company for a feasibility study for a totally different use (irrigation agriculture). In fact, it was the same DWA, through the Water Act, that allocated the MoA water rights to use the Ramotswa well fields for irrigation, and the MoA has since purchased land to that effect. This is a clear example of uncoordinated efforts going against the principles of IWRM by the two ministries that are located a few metres away from each other, and all sit in most of the master plans mentioned above.

In terms of capacity, there is generally sufficient capacity though limited in most cases to headquarters located in towns and cities. But this capacity is incoherent and sector specific. The incoherence is evident even in institutions and departments within the same ministry. Capacity building in this respect therefore relates to lack of capacity to work together in an integrated manner, which is another strong diagnosis in this paper. Of course, also critical to capacity building are data interpretive skills, which are lacking in most cases. 
3.3.4 Management instruments

This section addresses different management instruments commonly used to define the IWRM approach to resources management. Botswana is generally doing well in terms of assessment of the water resources, i.e. identifying water resources. For example, the Shashe water system (in its entirety, including the lower Shashe scheme), Letsibogo and many of the existing well fields are well located in areas with substantial water resources. There is of course room for improvement, e.g. the need to capitalize on the natural recharging systems such as in the Dukwe/Mosetse areas where the Makgadikgadi system can naturally recharge any water source in the area. What is eminent as a problem is the lack of IWRM/WE plans, which in principle would assist in efficiently managing and controlling existing sources rather than spending huge budgets on establishing new sources which in most cases come without efficiency mechanisms. In the southeastern part of Botswana which is severely affected by drought, and some parts of the northern area which have problems of water shortage, it is recorded that water losses through village distribution networks is in excess of 40\% [9]. So water efficiency plans could help remedy the situation of water losses through water saving technology and proper maintenance. If these problems continue, Botswana will inevitably miss the deadline of the 2002 WSSD call for all developing countries to develop IWRM/WE plans by the end of 2005. Besides losses, there are challenges of competing land uses closer to water supply dams. This is because the WUC, which is responsible for management of dams and their catchments, is restricted within the premises of the fences, beyond which it has no control over how land is used. This coupled with institutional fragmentation emphasized above make the sources vulnerable to siltation and pollution, which ultimately have a bearing on the effective dam capacity and lifespan. Farmers living close to these sources have found a way of watering their livestock in these resources against the plans of the government.

IWRM therefore helps to consolidate varying and sometimes competing uses including defining the use of space in and around water sources. The Gaborone dam catchment area presents one such failure where economic developments have taken place disregarding the critical need to protect water as a scarce resource in Botswana. This, and other land use developments, and encroachments within the catchment area could be the reasons behind the mysterious catchment-inflow failure in the Gaborone dam, when there was no significant inflow to the dam within the last 4 years despite some significant rainstorms recorded within the catchment.

Water resource conservation is another critical management instrument. It is critical for the sustainability of the supply of quality water resources and the healthy environment, which holds the water as a resource. Unsound management of the environment influences the quality and quantity of the water resources available both at the surface and underground levels. IWRM provides for accountability to resource use by encouraging management, which includes management of end products (waste). The Polluter Pays Principle and the Precautionary Principle are more applicable in the conservation and management of the resources, if sustainability is to be achieved. Also critical to the conservation strategy are instruments such as resource Life Cycle Analysis, resource reuse, recycling and reduction in the quantity of use. These conservation principles are only applied at a minimal scale in Botswana and are only limited so far to reducing the quantity of use.

Linked to the conservation is exploration and assessment of alternative water sources to prolong or augment the supply of the existing resources. Readily available is the wastewater, which currently is treated through biological means, and the DWA is working tirelessly to lobby for the use of treated wastewater for potable use. Another inevitable (in the long run) source is the international rivers such as Okavango, Chobe/Zambezi, etc. Both the above-mentioned sources are currently not exploited mainly because of an attitude factor and for political reasons, respectively. In terms of international sources, legal frameworks exist such as the SADC Water Protocol and implementation tools such as the Regional Indicative Strategic Development Plan (RISDP) and Regional Strategic Action Plan (RSAP) of 1999-2004. 
Water demand management as a management instrument ensures the wise use of resources. Water demand management encompasses identifying the varied use of the resource and allocating the resource efficiently and strategically within economically, socially and environmentally allowed atmospheres. Currently, politics, which unfortunately always disregards the economical vicissitudes and ecological integrity, sometimes overweighs supply.

Policy tools as management instruments comprise the use of regulatory and economic-based instruments in the management of natural resources. Regulatory instruments relate to command-and-control approaches such as standards, taxes and liability charges, while economic-based charges may again include taxes but together with market-based approaches such as creating incentives and disincentives for different interactions with the water resources. The market-based tools also include correctly pricing resources. These instruments are currently very minimally used if not totally unavailable.

Social change instruments encompass creating a buy-in in the processes and approaches adopted in the management of water resources. It therefore involves intensified education and awareness campaigns for the support of any initiatives geared towards improving the management of water and related resources. It should be noted that society also has a role to play since it influences policy decisions through elections. The responsible authorities are currently doing a lot in this endeavour although these are limited to urban centres. There is a need to cover all relevant areas especially where these resources are placed, and where there are evidences of water losses such as those areas mentioned above.

Information management and exchange is equally as critical as a management instrument. This includes packaging information, defining stakeholder base and disseminating the information to such. It is also critical to communicate the information at the right time, to the 'supposed to be recipients', and using socially and politically acceptable language (quality and media). Information management is currently not properly defined given the confrontations between the powers that be and the media, which are apparent from time to time.

\section{IWRM INITIATIVES IN SOUTHERN AFRICA, POTENTIAL PARTNERS FOR BOTSWANA WATER AUTHORITIES AND CONSOLIDATED CASES}

\subsection{IWRM initiatives in Southern Africa and potential partners in IWRM}

Following the WSSD Plan of Implementation and the call for all developing countries to develop IWRM/WE plans by end of the year 2005, SADC through GWP-SA was mandated to facilitate and implement IWRM/WE plans within the region. GWP-SA facilitates IWRM/WE plans by providing technical and process guidance through the multi-stakeholder platforms established as CWPs, and these are useful in contributing to the development of plans in a participatory manner. These partnerships include government, civil society, private sector, research and academic institutions and thus provide a neutral platform for development of the IWRM/WE plans. There are currently 10 CWPs in the region; they include Botswana, Zimbabwe, Zambia, Malawi, Swaziland, South Africa, Lesotho, Tanzania, Namibia and the Democratic Republic of Congo. In many of these CWPs, including Botswana, frameworks for action, which set a solid platform for IWRM initiatives, were developed. It is through these processes that a Regional Framework for Action (RFFA) was established. The RFFA was very instrumental in informing the SADC Water Strategy to align it with IWRM approach. Currently GWP-SA, through CWPs is facilitating and guiding IWRM/WE plans within the region in partnership with donor agencies such as the Canadian International Development Agency, the Swedish International Development Agency, Dutch funding and the United Nations Development Programme-Global Environment Facility (UNDP-GEF). The countries mentioned above, including 
Botswana have been taken on board although at different paces and stages. Botswana, has also responded to the call for proposal by the UNDP-GEF IWRM/WE dispensation. Other initiatives include the Botswana Water Partnership's response to the call by GWP-SA proposals to CWPs under the Swedish International Development Agency programme [12]. It is through these windows of opportunities that Botswana should take advantage of the national drought crisis in order to develop strategies tied to integrated water demand management to attract funding from the possible sources mentioned above. In fact, GWP Stockholm has identified possible entry points for the development of IWRM activities. One of these points, which is relevant to the Botswana situation, include focusing on remedying a recurrent water-related problem hampering national development, such as reducing vulnerability to droughts and floods by enhancing coping strategies, both structural and non-structural [2].

\subsection{Consolidated practical IWRM related studies}

Having diagnosed the water governance situation in Botswana with regard to the IWRM approach, a summary of IWRM-related case studies drawn from within and outside the region is provided with some lessons to learn from in order to improve water governance in Botswana.

\subsubsection{The Lower Manyame Catchment, Zimbabwe}

The aim of the project was to demonstrate through IWRM the development of a catchment outline plan for better water management along the Zambezi River in Zimbabwe [13]. The project was initiated by GWP-SA in partnership with the Lower Manyame sub-catchment and Zimbabwe Water Partnership, alongside other stakeholders. While there were challenges in translating IWRM theory into practice, there were equally some achievements in that through collaboration and participatory involvement of stakeholders [13] the project attracted reasonable revenue collection, as driven by the understanding that water is not only a social good but also an economic good. Also, the project resulted in capacity building among the members, as well as five WATERNet research students who graduated with an MSc degree in IWRM from the University of Zimbabwe. Involvement of international research organizations improved the profile and credibility of the project. On policy and legislative issues, the multi-stakeholder project met real needs on the ground for statutory requirements (i.e. review and assessment, and implementation of the Water Act) [13].

\subsubsection{IWRM/WE approach in Yemen}

According to GWP [2] Yemen's move towards IWRM was part of a series of economic, financial and administrative reforms designed to bring the country's economy back from the brink of collapse. Severe groundwater mining for irrigation in many basins was costing the country approximately US $\$ 0.5$ billion per year. The study further states that institutional fragmentation, poor governance and inadequate policy frameworks marked the country's water management. Through the IWRM approach policy makers were able to address the groundwater-mining problem using a more effective multipronged approach, including reducing subsidies on diesel fuel and eliminating subsidies on pumping equipment. This in turn helped in strategically transferring the country's scarce resources from agriculture, which uses more than $85 \%$ of the water but contributes only $15 \%$ to GDP, to higher value uses of water.

\subsubsection{The northern France case}

A related study [2] provides another case of high abstraction rates from the cities of France. Although the users proposed a supply based solution, of either building a dam on a river 30 miles away and piping water in or building a desalination plant at the cost of US\$1 billion, the policy makers chose 
a demand-based solution instead: they imposed a small tax on each cubic meter of water pumped from the aquifer. This tax made industries and cities reduce their water consumption. As a result groundwater use in the area became sustainable [2].

The three case studies provided above have rich lessons for Botswana water authorities. The first one demonstrates that even at a sub-catchment level or rural water supply level, it is possible to apply IWRM through coordinated efforts by local residents (who at the end have ownership and become accountable for the use of the resource) and technical experts, researchers, as well as policy makers to achieve the result stated above. The Yemen case shows that even when water conflicts are a result of institutional fragmentation and inadequate policy frameworks at a national level, such as Botswana [11], an integrated water demand management through economic instruments and strategic allocation (efficiency) can save the country US $\$ 0.5$ billion per year. Finally the France experience, though related to the Yemen case, is unique in the sense that rather than spending more money on infrastructure development and identification of alternative sources of water for industrial and municipal uses as cited above, imposition of appropriate user charges can reduce the demand and make the limited resource become sustainable. It is very interesting to note that all these examples depict the current water management and availability crisis in Botswana and therefore provides solutions and entry points for IWRM process in the water sector.

\section{CONCLUSIONS AND RECOMMENDATIONS}

Following the discussions above within the diagnosed status quo of water governance in Botswana in relation to the IWRM approach and the status of water-related drought in Botswana, the paper concludes that while there are some indications that water authorities desire to move towards an integrated water resources management direction, there is need for pragmatic change towards IWRM in the way water resources are managed and used in Botswana- a complete shift from sectoral to integrated management, from top-down to stakeholder participation, and demand responsive approaches, from command and control to more cooperative and distributive forms of water governance, from closed expert-driven and self-monitoring management to more open, transparent and communicative bodies, all aimed at effective water resources management which can help in containing the effects posed by water-related drought in Botswana.

Starting with policy makers, researchers and technical experts to users there is need for coordination in the way water and land related resources are managed. Also there is need for cross-sectoral involvement as well as institutional alignment in order to respond to the realities of extreme disasters such as drought and the escalating water demand in Botswana. The use of economic and regulatory instruments as a way of containing water demand across all areas of Botswana is encouraged. Effective communication and education strategies, which go beyond just raising awareness to more stakeholder participation, can be achieved through effective collaborative capacity building and competence across all groups. Since IWRM seeks a balance between the three Es (efficiency, equity and environmental sustainability) the paper recommends the following points as a way forward in meeting the challenges of drought in Botswana through an integrated approach.

1. An enabling legal framework: The paper fully appreciates the process in place to reform the legal and institutional framework through a review of the National Water Master Plan, Privatization Policy, development of the Water Policy, etc. Such initiatives will be better placed if they are aligned with the regional strategies such as SADC—Regional Water Strategy (under development), RSAP, RISDP and RFFA all geared towards IWRM, to mention a few. Water authorities must therefore clearly define their needs based on the opportunities provided within these initiatives and the local conditions where change can be effected. Also, the roles to be played by different groups (users, technical experts and policy makers) and their responsibilities should be 
clearly defined. In formal sectors such as government institutions such accountability could be tied to performance contracts under the new Performance Based Reward System.

2. Water demand management through appropriate economic and regulatory approaches. The case studies provided throw light on the advantages of proper imposition of incentives and disincentive approaches, as well as strategic water allocation to high-value uses of water than in areas where there are less tangible benefits at the municipal or national scale. The fact that water authorities managed to achieve a 35\% reduction in water use compared to the planned $25 \%$ reduction after the 2004 water restrictions shows that consumption can still be reduced far beyond $35 \%$ with more stringent restrictions, removal of water wasting structures such as automatic flushing urinals and leakage controls.

3. Strategic collaboration with various institutions: Having identified the roles to be played by different groups and institutions, water authorities should therefore strategically collaborate including working with institutions of learning and research to address priority needs beyond their capacity and mandate. For better communication and mobilization, the importance of NGOs, traditional groups and religious groups cannot be overemphasized and therefore should be part of an integrated system within water resource management strategies.

4. Developing management strategies: Water management should go beyond the borders of water sectors to an all encompassing approach where other ministries could have interest, e.g. planners, land authorities, agriculture and related areas. This will create a coordinated atmosphere in the management of water and will reduce potential conflicts for future developments. Vertical and horizontal linkages are important and should be defined.

5. Wastewater management and utilization: With so much of wastewater produced in the country, there is a need to seriously consider potential reuse areas through research and calibration of technology in order to satisfy local and international standards. It should be understood that wastewater can be recycled or used for other uses other than consumption including use in recharging existing water sources.

6. Exploring further watercourses: As Botswana shares some rivers with the neighbouring countries, there is a need for development of Trans-boundary Diagnostic Analysis as well as Strategic Action Plans for possible use of shared watercourses so that national resources can be augmented.

7. Environmental sustainability of catchments and watercourses: Using environmental assessment tools (such as environmental impact assessments and strategic environmental assessments) there is a need to ensure the integrity of the catchments as this will not only sustain the vital ecosystem but will also maintain the capacity of dams, reducing siltation and blockage and divergence of channels. The paper recommends that water authorities' mandate in the form of management plans should be extended beyond the current buffer zones to the entire catchment in the case of dams and rivers or beyond meters for household water consumption.

8. Information and communication strategy: It has already been implied that through collaboration and coordinated approach, effective communication strategies can be achieved. The challenge here is to define what and when, how and to whom information can be availed and/or revealed but still remain transparent, open and communicative.

\section{REFERENCES}

[1] Global Water Partnership, IWRM Tool Box Version 2: Sharing Knowledge for Equitable, Efficient and Sustainable Water Resources Management, The Press Works: UK, pp. 1-4, 2003.

[2] Global Water Partnership Technical Committee, Catalyzing Change: A Handbook for Developing Integrated Water Resources Management (IWRM) and Water Efficiency Strategies, Elanders: Stockholm, Sweden, pp. 9-12, 2004. 
[3] Gaselemogwe, S., Water Utilities Corporation Drought Management Model. Proc. of the National Drought Planning Workshop on Water Demand Management: The Key to Sustainable Supply, Gaborone, Botswana, 2005.

[4] Kenabatho, P.K. \& Parida, B.P., Evaporation losses as a major factor in determining allowable yield from water supply reservoirs: the case of Botswana's major reservoirs. River Basin Management III, eds. C.A. Brebbia \& J.S. Antunes do Carmo, WIT Transactions on Ecology and Environment, Vol. 83, WIT Press: Southampton, UK, pp. 631-638, 2005.

[5] Gaolathe, B., Meeting the Millennium Development Goals and Vision 2016 Through a SelfReliant Approach to Development, The Budget Speech, Government Printer: Gaborone, Republic of Botswana, pp. 4-15, 2005.

[6] Central Statistics Office, Population and Housing Census: Population of Towns, Villages and Associated Localities, Government Printer: Republic of Botswana, 1981, 1991 and 2001.

[7] Water Utilities Corporation, Briefing notes for the press on the drought situation, Gaborone, Botswana, 2004.

[8] Water Utilities Corporation, Public notice: Update on the drought situation, The Botswana Gazette, p. B2, 8 June 2005.

[9] Department of Water Affairs, Annual Report 2002/03, Quick Print: Gaborone, Botswana, 2003.

[10] Global Water Partnership-Southern Africa, Water for the 21st Century: Vision to Action, GWP: Sweden and Zimbabwe, pp. 21-24, 2000.

[11] Jansen, R, Kenabatho, P.K., Rakaisa, D. \& Montshiwa, M. (eds). Proc. of the Preliminary Consultative Workshop on SADC Vision for Water, Life and Environment and Framework for Action, GWP-SA/CWP Botswana: Gaborone, 2004.

[12] Kenabatho, P.K. \& Montshiwa, M., Water Use and Conservation Project Proposal, submitted to GWP-SA for funding, 2005.

[13] Global Water Partnership-Southern Africa, Chair's Report and Executive Secretary's Report, 5th Consulting Partners Meetings, Harare, Zimbabwe, pp. 4-17, 2005. 